\title{
The Effects of Canavanine and of Arginine Starvation on Macromolecular Synthesis in Chlamydomonas reinhardi
}

\author{
By D. MCMAHON and the late P. LANGSTROTH \\ Division of Biology, California Institute of Technology, \\ Pasadena, California 91 109, U.S.A.
}

(Received 22 October 197I; revised 12 June 1972)

\begin{abstract}
SUMMARY
Chlamydomonas reinhardi, starved of arginine, stopped growing but remained viable and continued to make protein. Synthesis of DNA and the accumulation of stable species of RNA were severely inhibited. Synthesis of rapidly labelled RNA was initially inhibited, but only temporarily, and finally rapidly labelled RNA was made faster than with arginine. These disturbances in nucleic acid metabolism were not related to changes in the pool sizes of nucleotide triphosphates, nor were any new nucleotides, such as guanosine tetraphosphate, detectable. When arginine in the medium was replaced by canavanine, the cells lost their chlorophyll, became non-motile, and non-viable. Canavanine rapidly inhibited the synthesis of RNA, but only inhibited the incorporation of amino acids into protein or the synthesis of DNA after a long lag. The size of the pools of nucleotide triphosphates and the pattern of their labelling with adenine was changed. These effects were consistent with a mechanism of killing, involving replacement of arginine by canavanine, by the cytoplasmic protein-synthesizing system. This protein then prevented all RNA synthesis. No changes in the structure of the nucleus were detected. Chlamydomonas reinhardi, therefore, differs from Escherichia coli in its response to arginine starvation or treatment with canavanine.
\end{abstract}

\section{INTRODUCTION}

Escherichia coli, starved of arginine, stops dividing but remains viable (Schachtele \& Rogers, 1965). Starvation of amino acids prevents the initiation of DNA synthesis (Maaløe \& Hanawalt, I96I ; Lark \& Lark, 1964) and inhibits RNA synthesis, except in some mutants in the RC (RNA Control) gene (Stent \& Brenner, 196I). The product of this gene controls the production of a variety of phosphorylated compounds. In wild-type organisms starved of an amino acid, an isomer of guanosine tetraphosphate becomes the second most abundant nucleotide in the cell and the purine nucleotide triphosphates decrease in concentration (Cashel \& Gallant, I969; Irr \& Gallant, 1969).

Eukaryotes respond to amino acid starvation in a similar manner (e.g. Sköld \& Zetterberg, 1969). Starvation of amino acids inhibits protein and DNA synthesis but not RNA synthesis in mouse fibroblasts (Sköld \& Zetterberg, 1969). DNA, RNA and protein synthesis are all inhibited in HeLa cells which are similarly treated (Maden, Vaughan, Warner \& Darnell, 1969; Bölcsföldi, Lambert \& Eliasson, 1971). However, there have been no attempts to determine whether a derangement of nucleotide metabolism similar to that in Escherichia coli is associated with inhibition of nucleic acid synthesis. We have investigated effects of arginine starvation on Chlamydomonas reinhardi, and in particular whether effects on nucleotide metabolism similar to those in $E$. coli are associated with the inhibition of nucleic 
acid synthesis. We have also examined the effects of an analogue of arginine, canavanine, which is structurally very similar but has a much less basic guanidinium group (Bell, 1965). It kills $E$. coli and inhibits the growth of a broad spectrum of eukaryotic organisms (e.g. Horowitz \& Srb, I948; Bonner, 1949; Shepherd \& Mandryk, 1964). Schachtele \& Rogers, 1965; I968), examining the effect on $E$. coli of canavanine, observed killing with exponential kinetics, after a lag, because of its incorporation into proteins. RNA synthesis and the ability to initiate DNA synthesis were also rapidly inhibited, but protein synthesis ceased only when the ribosomes were depleted of mRNA. Large proteinaceous canavanine-containing bodies, associated with the cell membrane, were produced and the nucleoplasm was disrupted (Schachtele, Anderson \& Rogers, 1968). Similar morphological effects occur using other amino acid analogues (Rabinowitz, Finkleman, Reagan \& Breitman, I969). In $E$. coli the synthesis of at least two proteins is required for the initiation of DNA synthesis and Schachtele \& Rogers (1968) believed that canavanine incorporation into at least one of these proteins disrupts the nucleoplasm and nucleic acid synthesis. The effects of canavanine on eukaryotes have been only slightly investigated. Walker carcinoma cells also incorporate canavanine into protein (Kruse, White, Carter \& McCoy, 1959) and preparations from rat liver attach canavanine to arginyl tRNA (Allende \& Allende, 1964). Canavanine also inhibits yeast alcohol dehydrogenase in vitro at concentrations similar to those effective for inhibition of cell growth $\left(5 \times 10^{-4} \mathrm{M}\right.$ and greater). Arginine does not inhibit the enzyme nor can the effect of canavanine be reduced by arginine (Tschiersch, 1966).

Treatment with canavanine and starvation for arginine provide an opportunity to study the interrelationships of macromolecular synthesis and amino acid metabolism in a eukaryote, and to compare them with previous studies of a prokaryote. If canavanine did kill eukaryotes by incorporation into proteins which disrupt nucleic acid synthesis, it could provide a means for selection of mutants defective in macromolecular synthesis (McMahon, 1971).

\section{METHODS}

Cells and culture conditions. Three strains of Chlamydomonas reinhardi were used, 89, a wild-type strain obtained from Dr K. S. Chiang, Department of Biophysics, University of Chicago, Chicago, Illinois, U.S.A.; $\arg 2$, a mutant which lacks arginosuccinate synthetase (Hudock, 1963), was obtained from Dr W. Ebersold, Department of Botany, University of California, Los Angeles, California, U.S.A.; a mutant conditionally defective in protein synthesis, $t s-I$, was isolated (McMahon, 197I). All experiments were performed in the high salt minimal medium of Sueoka (I960) containing 24 mM-sodium acetate (HSMA). For $\arg 2$ this medium was supplemented with $5.7 \times \mathrm{IO}^{-4} \mathrm{M}$-arginine (HSMA $+\arg$ ), except where noted. The cells were grown with constant stirring at $22{ }^{\circ} \mathrm{C}$ and under constant light intensity of $\mathrm{I} 500 \mathrm{~lx}$.

Cells were harvested by centrifugation for I min at $750 \mathrm{~g}$. They were washed in $0.15 \mathrm{M}-$ $\mathrm{NaCl}$, or HSMA if they were changed to a new medium. All experiments were performed in a Scherer controlled environment chamber at $33{ }^{\circ} \mathrm{C}$, with an illumination of $1500 \mathrm{~lx}$ except where noted. Unless mentioned, arg 2 was used in all experiments.

Measurement of cell components and of cell number. Protein synthesis was measured with $\left[{ }^{3} \mathrm{H}\right]$ arginine (generally labelled, $7 \cdot 0 \mathrm{mCi} / \mathrm{mm}$ ) at an activity of $0.2 \mu \mathrm{Ci} / \mathrm{ml} ;\left[4,5^{-} \mathrm{H}\right]$ leucine $(52 \mathrm{mCi} / \mathrm{mm})$ at an activity of $2 \mu \mathrm{Ci} / \mathrm{ml}$; or $\left[{ }^{14} \mathrm{C}\right]$ guanido-DL-canavanine $(33 \mathrm{mCi} / \mathrm{mm})$ at an activity of $0.5 \mu \mathrm{Ci} / \mathrm{ml}$; and sufficient non-radioactive L-canavanine sulphate to produce a final concentration of $3.5 \times 10^{-5} \mathrm{M}-\mathrm{L}$-canavanine. This concentration of canavanine was also used to measure canavanine transport. Samples of cells, which had been incubated with 
canavanine, were washed on to a Whatman GF/C filter moistened with HSMA and $3.65 \times$ $\mathrm{IO}^{-4} \mathrm{M}$-L-canavanine sulphate, then washed three times with $\mathrm{IO} \mathrm{ml}$ of the same solution. The filters were dried for $0.5 \mathrm{~h}$ at $100{ }^{\circ} \mathrm{C}$ and digested for $0.5 \mathrm{~h}$ at $70{ }^{\circ} \mathrm{C}$ in hyamine hydroxide. Ten $\mathrm{ml}$ of toluene-based scintillation counting fluid was added after the samples had cooled. The incorporation of (generally labelled) $\left[{ }^{3} \mathrm{H}\right]$ adenine into nucleic acids was measured with a quantity of $\left[{ }^{3} \mathrm{H}\right]$ adenine which gave an activity of 0.2 or $0.4 \mu \mathrm{Ci} / \mathrm{ml}$. Measurement of the incorporation of these precursors into protein or nucleic acids was described (McMahon \& Blaschko, I97I). Every point is the mean of two determinations.

The rate of incorporation of arginine into protein per cell was independent of cell concentration, for concentrations of $\mathrm{I} \cdot \mathrm{I} \times \mathrm{IO}^{5}$ to $\mathrm{I} \cdot \mathrm{I} \times \mathrm{I}^{6}$ cells $/ \mathrm{ml}$. However, the incorporation of adenine into RNA or DNA/cell is not proportional to cell number. It declines exponentially when plotted against the number of cells. This may result from a decrease in the average intensity of light which reaches each cell as a result of mutual shading.

The specific radioactivity of the nucleotide pools was measured by labelling the cells first with $\left[{ }^{32} \mathrm{P}\right]$ phosphoric acid $(2 \mu \mathrm{Ci} / \mathrm{ml})$ in $\mathrm{HSMA}+$ arginine with one-tenth of the normal concentration of phosphate. Cells were grown for $\mathrm{I} 4 \mathrm{~b}$, centrifuged and resuspended in identical fresh medium which also contained $0 \cdot 4 \mu \mathrm{Ci} / \mathrm{ml}$ of $\left[{ }^{3} \mathrm{H}\right]$ adenine $(7 \cdot 4 \mathrm{mCi} / \mathrm{mm})$. They were incubated for $2 \mathrm{~h}$ and then extracted and chromatographed by the method of Nazar, Lawford \& Wong (1970), on polyethyleneimine plates prepared by the method of Randerath $\&$ Randerath (I967). The individual nucleotides were located with the aid of carrier nucleotides, extracted with $0.1 \mathrm{~N}-\mathrm{HCl}$ and counted in dioxane-based scintillation fluid. In an attempt to detect the synthesis of new nucleotides, particularly guanosine tetraphosphate, the activity of ${ }^{32} \mathrm{P}$ was increased to $30 \mu \mathrm{Ci} / \mathrm{ml}$, nucleotides were extracted and chromatographed by the methods of Cashel (1969) and sections of the entire chromatographic lane counted in a scintillation counter (the limit of detection of this method is $5 \mathrm{pmol}$ of nucleotide/10 $10^{8}$ cells; Nazar et al. 1970 ) or the entire chromatogram was scanned with a Berthold chromatogram scanner (the limit of detection of this method is 300 to $400 \mathrm{pmol} / \mathrm{IO}^{8}$ cells). The ${ }^{3} \mathrm{H}$ label indicates the contribution of external adenine to the internal nucleotide pools and the ${ }^{32} \mathrm{P}$ label allows the size of these pools to be measured.

Chlorophyll was measured by the method of Arnon (1949). Cell structure was observed with a Zeiss phase contrast microscope. Cells were counted with a haemacytometer or a Coulter counter. Viable cells were measured in a $5 \mathrm{ml}$ sample of the culture. This was centrifuged and the supernatant was carefully decanted. The cells were resuspended in HSMA plus arginine and dilutions were plated on the same medium, solidified with $15 \mathrm{~g} / \mathrm{l}$ of agar. The colonies were counted after 3 to 4 days of incubation in continuous light ( $80001 \mathrm{x})$ and the rate constants for killing were calculated with standard least-squares regression techniques on the logarithmically transformed data.

Cells were prepared for electron microscopy by centrifuging and resuspending in paraformaldehyde-glutaraldehyde fixative $(4 \%, \mathrm{w} / \mathrm{v}$, paraformaldehyde plus $5 \%$, v/v, glutaraldehyde in $0.03 \mathrm{M}$-Sörenson's buffer-Sörenson, 1909), $\mathrm{pH} 7.2$, for $2 \mathrm{~h}$ at $25^{\circ} \mathrm{C}$. They were washed overnight in buffer, then packed into a hard pellet by centrifugation for $5 \mathrm{~min}$ at $7700 \mathrm{~g}$. After fixing in $\mathrm{I} \%, \mathrm{w} / \mathrm{v}, \mathrm{OsO}_{4}$ in $0.3 \mathrm{M}$-Sörenson's buffer for $2 \mathrm{~h}$, the pellet was dehydrated in a graded series of alcohol solutions and propylene oxide and embedded in epon. Sections were stained with $2 \%$ uranyl acetate followed by lead citrate (Reynolds, 1963).

Sources of chemicals. Radioactive chemicals were purchased from Schwarz BioResearch, Orangeburg, New York, U.S.A., and New England Nuclear, Boston, Massachusetts, U.S.A. L-Canavanine sulphate was the product of CalBiochem, La Jolla, California, U.S.A. Arginine was obtained from the Sigma Chemical Company, St Louis, Missouri, U.S.A. 


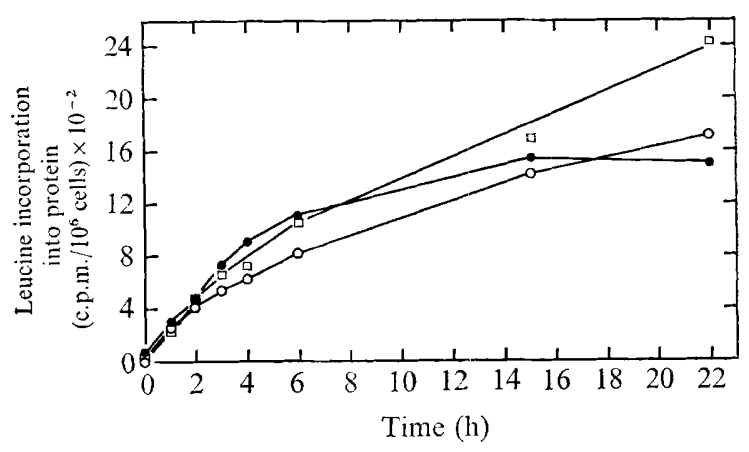

Fig. I

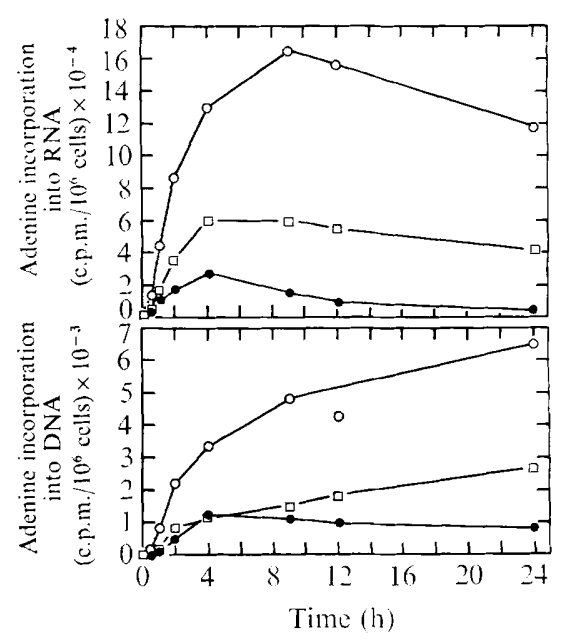

Fig. 2

Fig. I. The incorporation of $\left.{ }^{3} \mathrm{H}\right]$ leucine into protein in the absence of arginine or the presence of canavanine. Cells of $\arg 2\left(2.2 \times 10^{6} / \mathrm{ml}\right)$ were suspended in growth medium which contained $\left[{ }^{3} \mathrm{H}\right]$ leucine $(52 \mathrm{mCi} / \mathrm{mm})$ at a concentration of $2 \mu \mathrm{Ci} / \mathrm{ml}$. In addition the mixtures contained: O, $5.70 \times 10^{-4} \mathrm{M}$-arginine;, $3.65 \times 10^{-4} \mathrm{M}$-canavanine-SO ${ }_{4} ; \square$, nothing. At intervals, samples were analysed for their incorporation of $\left[{ }^{3} \mathrm{H}\right]$ leucine into protein.

Fig. 2. The effects of starvation for arginine or of canavanine on nucleic acid accumulation. $\operatorname{Arg} 2$ $\left(4.38 \times 10^{5}\right.$ cells $\left./ \mathrm{ml}\right)$ was incubated in growth medium with $0.4 \mu \mathrm{Ci} / \mathrm{ml}$ of $\left[{ }^{3} \mathrm{H}\right]$ adenine $(22 \mathrm{Ci} / \mathrm{mm})$ plus: $O, 5.70 \times 10^{-4} \mathrm{M}$-arginine; $9,3.65 \times 10^{-4} \mathrm{M}$-canavanine-SO ${ }_{4} ; \square$, nothing. Top frame: incorporation into RNA. Bottom frame: incorporation into DNA.

Cycloheximide was from both these companies and chloramphenicol was the product of Parke-Davis Company, Detroit, Michigan, U.S.A. All other chemicals were reagent grade.

\section{RESULTS}

The effects of arginine starvation. Cells starved of arginine stop dividing but remain viable for over $36 \mathrm{~h}$ ( $>4$ generation times). Although the net synthesis of proteins ceases (Jones, Kates \& Keller, I968), some protein synthesis does occur. Incorporation of $\left[{ }^{3} \mathrm{H}\right]$ leucine into protein continues for at least $15 \mathrm{~h}$ (Fig. I). Identical results were obtained in three other experiments using $\left[{ }^{3} \mathrm{H}\right]$ leucine or $\left[{ }^{3} \mathrm{H}\right]$ phenylalanine to label protein. These results disagree with those of Jones et al. (1968) who failed to incorporate precursor into protein $2 \mathrm{~h}$ after $\arg 2$ cells were starved of arginine. The apparently greater rate of leucine or phenylalanine incorporation in starved cells may reflect either a greater rate of protein synthesis or an increase in the specific activity of the precursor pool.

Within $\mathrm{I} h$ the incorporation of $\left[{ }^{3} \mathrm{H}\right]$ adenine into DNA and RNA is inhibited (Fig. 2). Labelling times longer than $\mathrm{I}$ h emphasize the accumulation of stable species of RNA in Chlamydomonas reinhardi. Arginine starvation does not inhibit all RNA synthesis (Fig. 3). In this experiment the control cells show a stimulated incorporation of adenine into RNA, but after $2 \mathrm{~h}$ the rate has declined to the initial rate. This is probably a reaction of the cells to the change in temperature. Starved cells do not show the initial stimulation by higher temperature but their apparent rate of RNA synthesis continues to increase and surpasses that of the control cells. RNA synthesis is not depressed by starvation for arginine. Therefore 


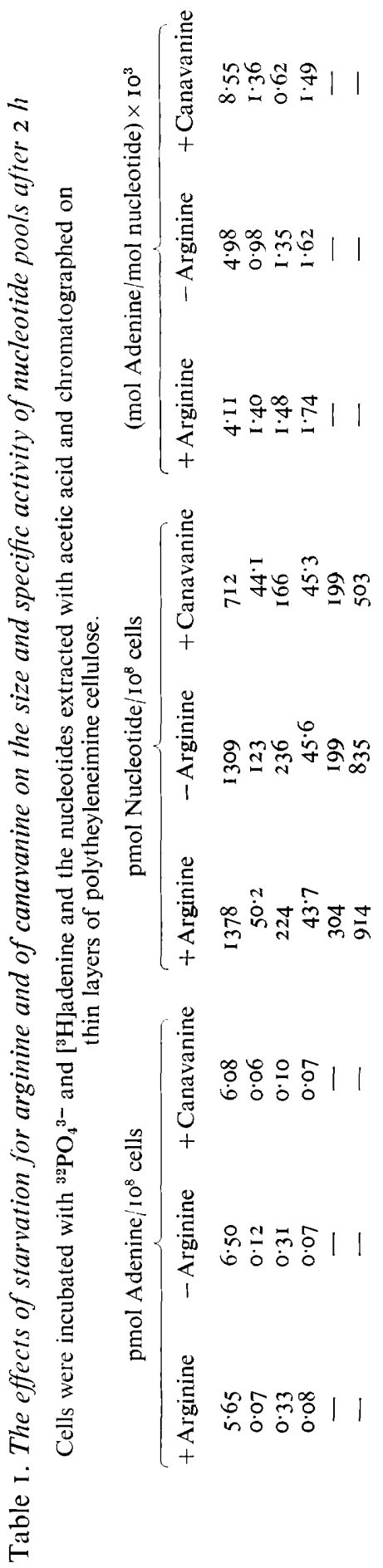

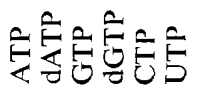




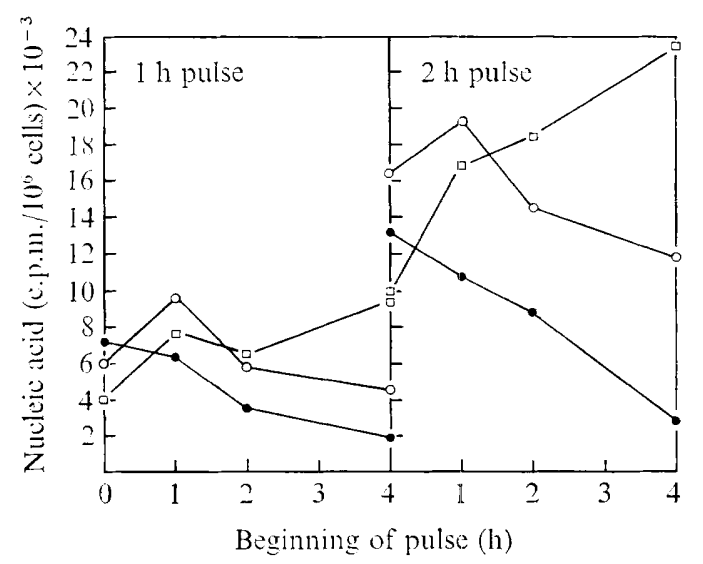

Fig. 3

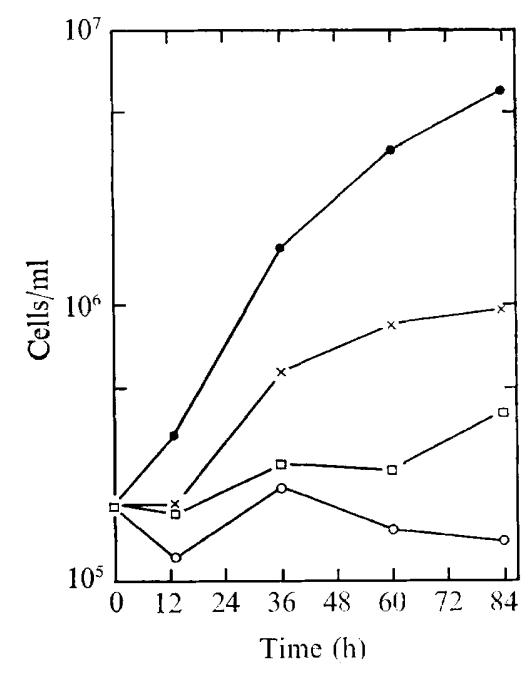

Fig. 4

Fig. 3. The effects of canavanine and of starvation for arginine on nucleic acid synthesis. Arg 2 cells $\left(1.52 \times 10^{6}\right.$ cells $\left./ \mathrm{ml}\right)$ were suspended in medium with arginine $\left(5.70 \times 10^{-4} \mathrm{M}\right), 0$; without arginine, $\square$; or with canavanine-SO $\mathrm{SO}_{4}\left(3.65 \times 1 \mathrm{IO}^{-4} \mathrm{M}\right)$, ๑. Cells were pulse-labelled with $\left[{ }^{3} \mathrm{H}\right]$ adenine $(\mathrm{I} \cdot 68 \mathrm{Ci} /$ $\mathrm{mM}), 0.4 \mu \mathrm{Ci} / \mathrm{ml}$, at the times which are indicated.

Fig. 4. Canavanine inhibits the multiplication of Chlamydomonas reinhardi. Chlamydomonas reinhardi, wild-type, were added to tubes of HSMA containing: $0,3.65 \times 10^{-3} \mathrm{M} ; \square, 3.65 \times 10^{-4} \mathrm{M}$; $\times, 3.65 \times 10^{-5} \mathrm{M}$; or , no L-canavanine- $\mathrm{SO}_{4}$. The initial concentration of cells was $\mathrm{I} \cdot 9 \times 1 ;{ }^{5} \mathrm{cells} / \mathrm{ml}$.

the rate of synthesis or of processing of stable RNAs must be selectively decreased by arginine starvation or alternatively these RNAs may be degraded more rapidly when the cells are starved.

These apparent rates are accurate reflexions of the true rate of synthesis of nucleic acid, at least at $2 \mathrm{~h}$ (Table $\mathrm{I}$ ), as the specific activity of the precursor pools remains relatively constant. Incorporation of ${ }^{3} \mathrm{H}$ into UTP and CTP is slight. In contrast to results obtained with Escherichia coli, there is little change in the pool sizes of the nucleotides and no new nucleotides were detected after arginine starvation. The inhibition of nucleic acid synthesis produced by starvation for arginine was completely reversible and the cells rapidly recovered normal rates of synthesis.

The effects of canavanine. Canavanine $\left(3.65 \times 10^{-3} \mathrm{M}\right)$ completely inhibits the growth of wild-type cells (Fig. 4), but the cells can survive, as less than $90 \%$ are killed after $35 \mathrm{~h}$. Cells which cannot manufacture their own arginine are more susceptible to canavanine, being killed without a lag and with first-order kinetics. The first-order rate constant, which is a function of canavanine concentration in these experiments, was $-0.28 \pm 0$. I I (mean $\pm 95 \%$ confidence limits), but this rate is a function of the concentration of canavanine in the medium, although a Ioo-fold increase in the concentration of canavanine only increases the rate of killing by two times $(-0.66 \pm 0.09)$. Arginine is a very effective competitor of canavanine. An equimolar concentration of arginine completely prevents the killing and even allows a small increase in the number of viable cells.

Both arginine-starved and canavanine-treated cells appear vacuolated when they are observed in the phase contrast microscope. The vacuoles resemble autophagic vacuoles in the electron microscope (Fig. 5). There appears to be no difference in the number or 

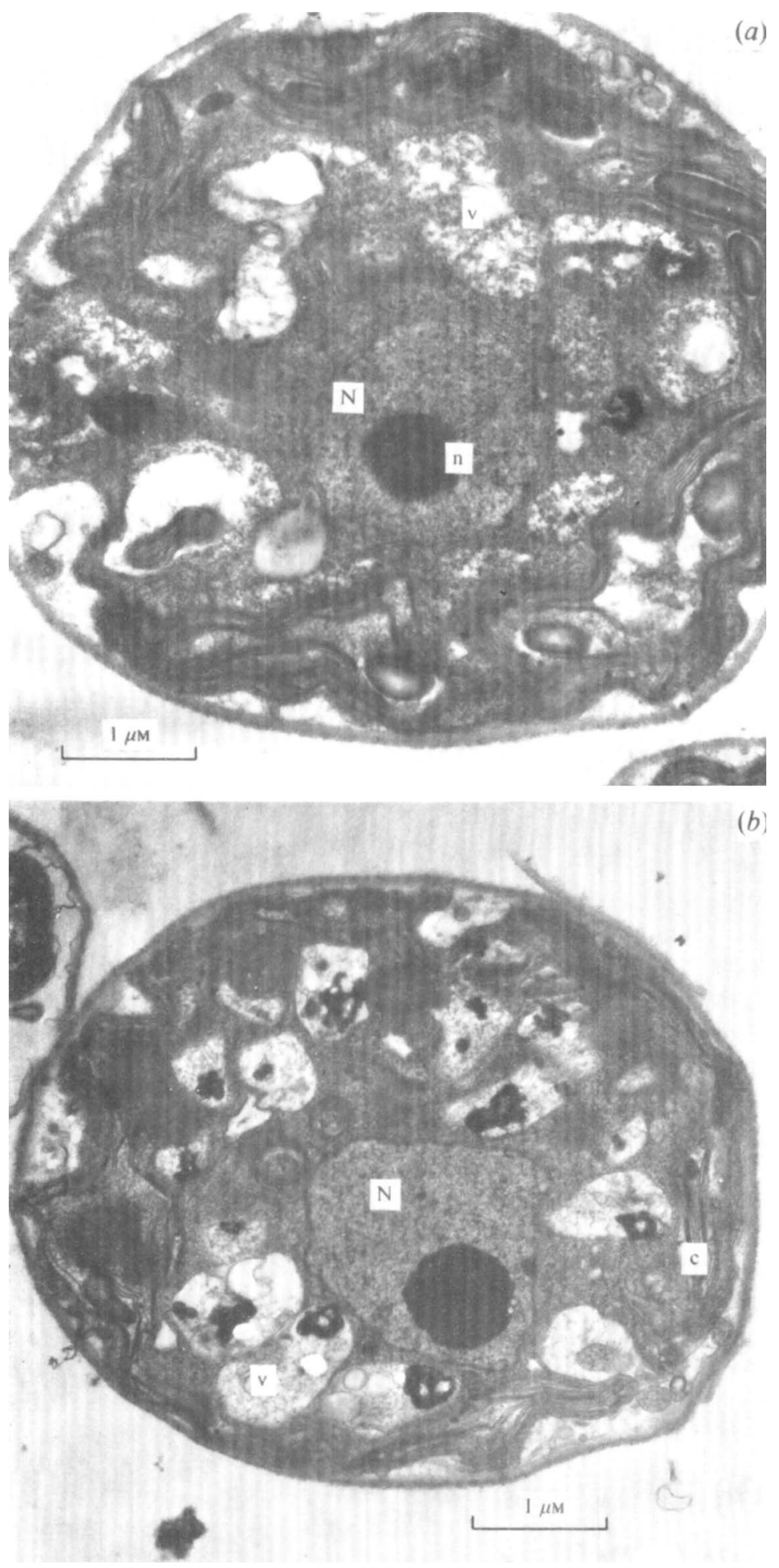

Fig. 5. The effect of arginine starvation or canavanine on cell structure. Arg 2 cells were treated with $3.65 \times 10^{-4} \mathrm{M}$-canavanine ( $a$ ) or starved for arginine (b), for $24 \mathrm{~h}$ before processing the cells for electron microscopy. $\mathrm{N}$, nucleus; $\mathrm{n}$, nucleolus; $\mathrm{c}$, chloroplast; $\mathrm{v}$, vacuole. 


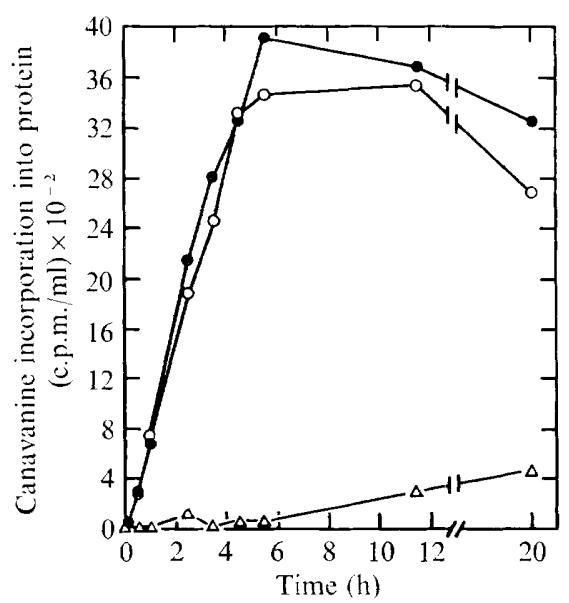

Fig. 6

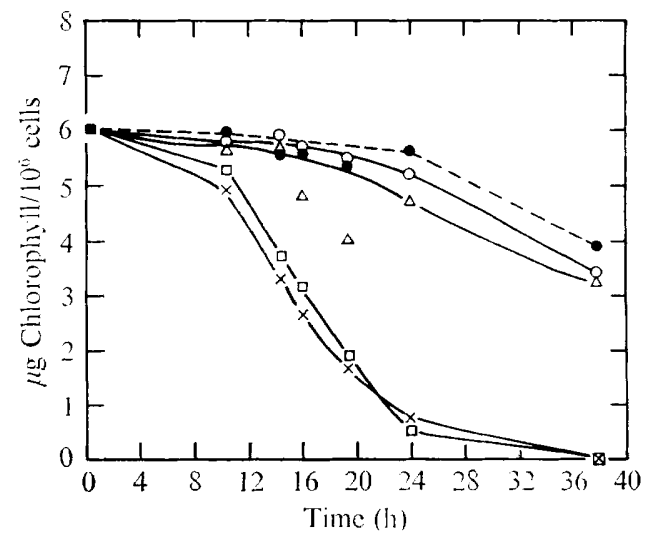

Fig. 7

Fig. 6. The effects of inhibitors of protein synthesis on the incorporation of canavanine into protein. $\operatorname{Arg} 2$ cells $\left(2.8 \times 10^{6} / \mathrm{ml}\right)$ were incubated in growth medium containing $0.5 \mu \mathrm{Ci} / \mathrm{ml}$ of $\left.{ }^{[14} \mathrm{C}\right] \mathrm{DL}$ canavanine $(33 \mathrm{mCi} / \mathrm{mm})$ plus sufficient non-radioactive canavanine to make a concentration of L-canavanine of $3.65 \times 10^{-5} \mathrm{M}$. The samples also contained: $\bullet$, nothing; $\Delta, 3.55 \times 10^{-5} \mathrm{M}$-cycloheximide; or $\mathrm{O}, 3^{\cdot} \cdot 00 \times 1 \mathrm{IO}^{-4} \mathrm{M}$-chloramphenicol. Incorporation of $\left[{ }^{14} \mathrm{C}\right]$ canavanine was measured at intervals.

Fig. 7. The effect of arginine starvation and canavanine on the chlorophyll content of cells. Flasks containing $\arg 2\left(\mathrm{I} \cdot 90 \times 10^{6} \mathrm{cells} / \mathrm{ml}\right)$ were incubated in growth medium plus: $\triangle$, nothing; $\square$, canavanine; $\bullet$, canavanine plus $3.55 \times 10^{-5} \mathrm{M}$-cycloheximide; $\times$, canavanine plus $3.00 \times 10^{-4} \mathrm{M}$-chloramphenicol; $\mathrm{O}$, canavanine plus $3.55 \times 10^{-5} \mathrm{M}$-cycloheximide plus $3.00 \times 10^{-4} \mathrm{M}$-chloramphenicol. All canavanine was present as $3.65 \times 10^{-4} \mathrm{M}-\mathrm{L}-$ canavanine- $\mathrm{SO}_{4}$. At intervals samples were analysed for their chlorophyll content.

appearance of these vacuoles in arginine-starved or canavanine-treated cells. There is no apparent disruption of the nucleus or nucleolus.

Canavanine inhibits RNA accumulation and synthesis. The accumulation of RNA is inhibited by canavanine in less than $\mathrm{I} h$ (Fig. 2). The rate of decrease in the rate of adenine incorporation into RNA is as fast or faster than the rate of death. The first-order rate constant for the change in the relative rate of adenine incorporation into RNAl(comparing cells treated with canavanine with those starved for arginine) is $-0.32 \mathrm{~h}^{-1}$ (Fig. 2). (This may underestimate the rate constant since the rate of adenine incorporation seems to overestimate the rate of RNA synthesis in canavanine-treated cells as will be discussed later.) Compare this to the rate constant for killing. Pulse-labels with $\left[{ }^{3} \mathrm{H}\right]$ adenine also showed a rapid decrease in the rate of RNA synthesis (Fig. 3) when cells were incubated in canavanine. The incorporation of adenine into DNA was relatively resistant to canavanine and not inhibited for at least $4 \mathrm{~h}$ (Fig. 2). In four other experiments there was no inhibition of $\left[{ }^{3} \mathrm{H}\right]-$ adenine incorporation into DNA for 8 to $12 \mathrm{~h}$. Canavanine had no effect on the incorporation of adenine into the DNA of wild-type cells but did inhibit its incorporation into RNA. Canavanine does not cause the production of new nucleotides but increases the specific activity of ATP by more than $100 \%$ and decreases that of GTP by about $60 \%$ (Table 1 ). If the ratio of GMP/AMP in the RNAs whose synthesis is being measured is 5 or less, the apparent rate of RNA synthesis in canavanine is greater than the actual rate. There are slight decreases in the specific activities of the deoxyribonucleotide triphosphates so the rate of DNA synthesis is at least as great in canavanine-treated cells as in arginine-starved cells. 


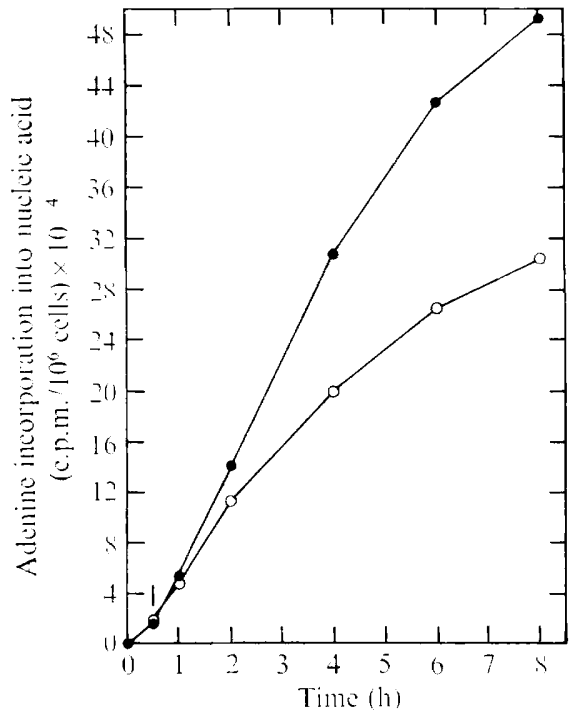

Fig. 8

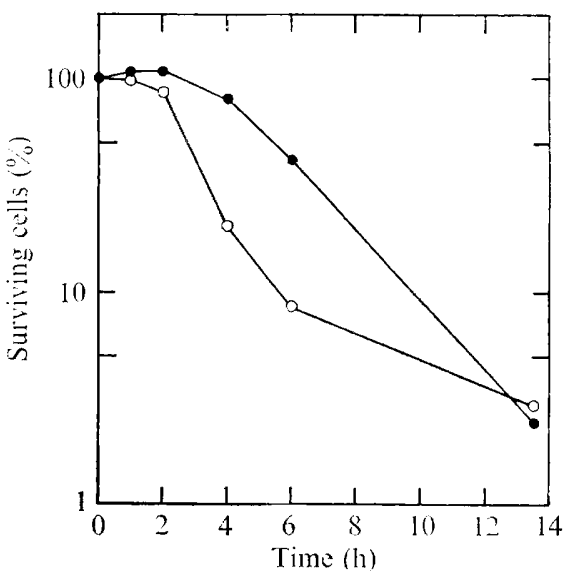

Fig. 9

Fig. 8. Prevention of the deleterious effects of canavanine on RNA synthesis in a temperaturesensitive mutant. TS $I\left(2.8 \times 10^{5}\right.$ cells $\left./ \mathrm{ml}\right)$ was suspended in growth medium with $\left[{ }^{3} \mathrm{H}\right]$ adenine, $0.4 \mu \mathrm{Ci} / \mathrm{ml}(\mathrm{I} \cdot 55 \mathrm{Ci} / \mathrm{mm})$, and incubated for $0.5 \mathrm{~h}$. Then one culture, $O$, was made $3.65 \times 10^{-4} \mathrm{M}$ in canavanine. An equivalent volume of distilled water was added to the other, $\bullet$.

Fig. 9. Cycloheximide partially protects cells against killing by canavanine. $\operatorname{Arg} 2$ was suspended in growth medium plus $3.65 \times 10^{-4} \mathrm{M}$-canavanine and nothing, $\mathrm{O}$, or $7.1 \times 10^{6} \mathrm{M}$-cycloheximide, The initial concentrations of cells were $7 \cdot 1 \times 10^{5} / \mathrm{ml}$. Viable cells were determined by plating.

The size of all of the ribonucleotide triphosphate pools is depressed by 35 to $50 \%$ but the dATP and dGTP pools are relatively resistant to canavanine. Treatment with canavanine had no detectable effect on the incorporation of leucine into protein for at least $6 \mathrm{~h}$ (Fig. I), but after $\mathrm{I} 6 \mathrm{~h}$ both protein and nucleic acid synthesis were completely and irreversibly inhibited.

The mechanism of action of canavanine. The greater susceptibility of $\arg 2$ than wild-type cells to canavanine implies that it may substitute for arginine, particularly as arginine completely suppressed the lethal effects of canavanine. Canavanine is readily incorporated into protein (Fig. 6) and after $6 \mathrm{~h}$ more than $95 \%$ of the canavanine in the cell is present in protein (D. McMahon, unpublished results). This incorporation is inhibited by cycloheximide $(3.55 \times$ $\left.\mathrm{IO}^{-5} \mathrm{M}\right)$ but not by chloramphenicol (Fig. 6). In contrast chloramphenicol $\left(3 \cdot 0 \times \mathrm{IO}^{-4} \mathrm{M}\right)$ inhibited the rate of incorporation of arginine into protein by $35 \%$ and cycloheximide inhibited its incorporation by $94 \%$. Therefore, the chloramphenicol-sensitive system of protein synthesis can incorporate arginine much more effectively than canavanine. The evidence presented so far suggests that canavanine is incorporated into a protein(s) by the cycloheximide-sensitive system. Cycloheximide also prevented the canavanine-induced bleaching of cells but chloramphenicol did not (Fig. 7).

Canavanine and cycloheximide both inhibit RNA synthesis but in combination inhibited less than each independently. This may indicate that a protein which contains canavanine stops RNA synthesis and thereby kills the cell. Further, mutants of Chlamydomonas reinhardi, which were conditionally resistant to canavanine (McMahon, I97I), were also conditionally defective in protein synthesis. This also indicated that canavanine killed the cell by incor- 
poration into a protein. Using one of these mutants which possessed a defect in protein synthesis at $33^{\circ} \mathrm{C}$, when protein synthesis was severely reduced the effects of canavanine on RNA synthesis were also reduced (Fig. 8). After $4 \mathrm{~h}$ in canavanine, the mutant was incorporating $\left[{ }^{3} \mathrm{H}\right]$ adenine into RNA at a rate which is $50 \%$ of the starved cells. In the $\arg 2$ strain incorporation almost completely stopped after $4 \mathrm{~h}$. Cycloheximide partially protected cells against canavanine killing (Fig. 9). The death of cells which occurs even in the presence of cycloheximide is probably the result of cycloheximide's own toxic effects.

\section{DISCUSSION}

Under the conditions used, Chlamydomonas reinhardi only partially resembles Escherichia coli in the way in which starvation for an amino acid affects it. Arginine starvation stops cell growth, but does not kill cells, and severely inhibits RNA accumulation and DNA synthesis. Some protein synthesis continues for long periods. These proteins either do not contain arginine or arginine is supplied to the cell by the turnover of previously synthesized proteins. The synthesis of rapidly labelled RNA is stimulated.

The requirement of arginine for DNA synthesis may reflect the synthesis of a protein for continuation of DNA synthesis. This is supported by mutants conditionally defective in protein synthesis which show greatly reduced rates of DNA synthesis under non-permissive conditions (McMahon, I97I). The slight effect of arginine starvation on the pool sizes of the ribo- and deoxyribonucleotide triphosphates contrasts with the effect of this treatment on Escherichia coli. In particular the absence of any detectable synthesis of guanosine tetraphosphate may mean that the mechanism of 'stringent' control of RNA synthesis is different. No detectable change in nucleotide metabolism can account for the stimulation of the synthesis of the rapidly labelled RNA.

When canavanine is substituted for arginine, it is incorporated into proteins and may substitute for arginine. Only the cycloheximide-sensitive system appears to make proteins which contain canavanine. Since mitochondrial and chloroplast protein synthesis is believed to be sensitive to chloramphenicol, these organelles must be unable to substitute canavanine for arginine. The discrimination against canavanine could occur at the organelle membrane or might be a specific characteristic of their protein synthetic apparatus. We cannot distinguish between these possibilities. In addition, the suggestion that canavanine must be incorporated into a protein in order to kill the cell is supported by canavanine selection for mutants of Chlamydomonas reinhardi which are conditionally defective in protein synthesis.

At least one of the canavanine-containing proteins kills the cell. The kinetics of inhibition of macromolecular synthesis suggest that this is a key protein associated with the synthesis of RNA, because only RNA synthesis is inhibited as rapidly as the cells are killed; therefore killing probably occurs by a different mechanism from Escherichia coli. A defective protein could be made which might then prevent transcription. Such a protein might disrupt the structure of the DNA template (as, for example, a histone with partial substitution of canavanine for arginine) or might prevent synthesis of stable RNAs by permanently lowering the pool sizes of ribonucleotide triphosphates. Such decreases do occur with canavanine and they are substantial in size.

Other effects of canavanine on nucleotide metabolism need not result from its incorporation into a protein. Canavanine can spontaneously cyclize into desaminocanavanine (Kitagawa \& Tsukamoto, 1937). This resembles orotic acid and might inhibit the synthesis of pyrimidines. Also arginosuccinase can catalyse the formation of canavinosuccinic acid (Walker, 1953), which resembles part of the molecule of adenylosuccinic acid and might 
interfere with the formation or cleavage of adenylosuccinate. This could affect the synthesis of both ATP and GTP and the conversion of adenine nucleotides into guanine nucleotides. These reactions could explain the observed pattern of canavanine's effects on nucleotide pool size and specific activities, but they are not likely to be responsible for the lethal effect of low levels of canavanine $\left(3.65 \times 10^{-4} \mathrm{M}\right.$ or less), because this requires the incorporation of canavanine into a protein.

The effects of canavanine on Chlamydomonas also resemble those on Escherichia coli in its ability in both micro-organisms to relieve partially the initial inhibition of the synthesis of RNAs produced by arginine starvation (Simonnet \& Chappeville, 1969). However, its incorporation into protein is probably responsible for the rapid inhibition of this initial effect. RNA and DNA synthesis are not completely inhibited for a generation in $E$. coli, viability is not affected for a generation, and protein synthesis continues for 2.5 generations. In Chlamydomonas reinhardi, viability decreases in $0 \cdot 1$ generation or less, whereas RNA and DNA synthesis is completely inhibited after about 0.5 generation. Protein synthesis, however, continues for I to I 5 generations. This implies that some mRNA can participate in protein synthesis for up to one generation in $C$. reinhardi.

For Chlamydomonas reinhardi there is no obvious effect of canavanine on the morphology of the nucleus and nucleolus which, as the sites of RNA synthesis, may be the loci of canavanine's effects. Starvation for arginine and substitution for arginine and canavanine appeared to be similar in both micro-organisms, but there are considerable differences between the basic biochemical and morphological effects of canavanine on these two types of cells.

We thank Mr William Fry for his skilled technical assistance. This research was supported by USPH Grant no. GM 06965 .

\section{REFERENCES}

Allende, C. C. \& Allende, J. E. (1964). Purification and substrate specificity of arginyl-ribonucleic acid synthetase from rat liver. Journal of Biological Chemistry 239, 1 102-1 106.

Arnon, D. I. (1949). Copper enzymes in isolated chloroplasts. Polyphenoloxidase in Beta vulgaris. Plant Physiology 24, I-15.

BELl, E. A. (I965). Homoarginine, $\gamma$-hydroxyarginine and related compounds. In Comparative Biochemistry of Arginine and its Derivatives, pp. 20-35. Edited by G. E. W. Wohlstenholme and M. P. Cameron. Boston: Little, Brown \& Co.

Bölcsföldi, G., LAMBERT, P. \& Eliasson, E. (1971). RNA metabolism in human cells during amino acid deprivation. I. Biochimica et biophysica acta 228, 664-675.

BoNver, J. (1949). Limiting factors and growth inhibitors in the growth of the Avena coleoptile. American Journal of Botany 36, 323-332.

CASHEL, M. (1969). The control of ribonucleic acid synthesis in Escherichia coli. IV. Relevance of unusual phosphorylated compounds from amino acid-starved stringent strains. Journal of Biological Chemistry 224, 3 I 33-3I 4 I.

Cashel, M. \& Gallant, J. (I969). Two compounds implicated in the function of the $R C$ gene of Escherichia coli. Nature, London 221, $838-84 \mathrm{I}$.

Horowitz, N. H. \& SRB, A. (1948). Growth inhibition of Neurospora by canavanine, and its reversal. Journal of Biological Chemistry 174, 371-378.

Hudock, G. A. (I963). Repression of arginosuccinase in Chlamydomonas reinhardi. Biochemical and Biophysical Research Communications Io, $133-138$.

Irr, J. \& Gallant, J. (I969). The control of ribonucleic acid synthesis in Escherichia coli. II. Stringent control of energy metabolism. Journal of Biological Chemistry 244, 2233-2239.

Jones, R. F., Kates, J. R. \& Keller, S. J. (1968). Protein turnover and macromolecular synthesis during growth and gametic differentiation in Chlamydomonas reinhardi. Biochimica et biophysica" acta I57, $589-598$. 
Kitagawa, M. \& Tsukamoto, J. (1937). Studies on a diamino acid, canavanin. VI. The formation of desamino canavanin from canavanin. Journal of Biochemistry 26, 373-385.

Kruse, P. F., Jun., White, P. B., CARTer, H. A. \& MCCoy, T. A. (I959). Incorporation of canavanine into protein of Walker carcinosarcoma 256 cells cultured in vitro. Cancer Research 19, I22-I25.

LARK, C. \& LARK, K. G. (I964). Evidence for two distinct aspects of the mechanism regulating chromosome replication in Escherichia coli. Journal of Molecular Biology ro, I20-1 36.

MCMAHON, D. (197I). The isolation of mutants conditionally defective in protein synthesis in Chlamydomonas reinhardi. Molecular and General Genetics 112, 80-86.

McMahon, D. \& Bl.ASChKo, W. (1971). Chloral hydrate inhibits protein synthesis in vivo. Biochimica et biophysica acta 238, 338-342.

MaAløe, D. \& Hanawalt, P. C. (1961). Thymine deficiency and the normal DNA replication cycle. I. Journal of Molecular Biology 3, I44-I 55 .

Maden, B. E. H., Vaughan, M. H., Warner, J. R. \& Darnell, J. E. (I969). Effects of valine deprivation on ribosome formation in HeLa cells. Journal of Molecular Biology 45, 265-275.

NAZAR, R. N., LawFord, H. G. \& WoNG, J. J. (I970). An improved procedure for the extraction and analysis of cellular nucleotides. Analytical Biochemistry 35, 305-31 3.

Rabinowitz, M., Finkleman, A., Reagan, R. L. \& Breitman, T. R. (I969). Amino acid antagonist death in Escherichia coli. Journal of Bacteriology 99, 336-338.

RANDERATH, K. \& RANDERATH, E. (1967). Thin layer separation methods for nucleic acid derivatives. In Methods in Enzymology, vol. XII, pp. 323-347. Edited by N. O. Kaplan. New York: Academic Press.

REYNOLDS, E. S. (1963). The use of lead citrate at high $\mathrm{pH}$ as an electron-opaque stain in electron microscopy. Journal of Cell Biology 17, 208-212.

Schachtele, C. F., ANDereson, D. L. \& Rogers, P. (1968). Mechanism of canavanine death in Escherichia coli. II. Membrane-bound canavyl-protein and nuclear disruption. Journal of Molecular Biology 33, 861-872.

Schachtele, C. F. \& Rogers, P. (1965). Canavanine death in Escherichia coli. Journal of Molecular Biology I4, 474-489.

SCHACHTELE, C. F. \& Rogers, P. (1968). Mechanism of canavanine death in Escherichia coli. I. Effect of canavanine, on macromolecular synthesis. Journal of Molecular Biology 33, 843-860.

SHEPHERD, C. J. \& MANDRYK, M. (1964). Effects of metabolites and antimetabolites on the sporulation of Plenospora tabacina Adam. on tobacco leaf disks. Australian Journal of Biological Sciences 17, 878-89I.

Simonnet, G. M. \& Chappeville, F. (I969). Action de la canavanine sur la synthèse du RNA chez E. coli. European Journal of Biochemistry 9, 199-206.

SKöLD, O. \& ZETTERBERG, A. (1969). Studies on the amino acid regulation of RNA synthesis in mammalian cells in tissue culture. Experimental Cell Research 55, 289-294.

SöRENSON, S. P. L. (1909). Ergänzung zu der Abhandlung: Enzymstudien II: Über die Messung und die Bedeutung der Wasserstoffionenkonzentration bei enzymatischen Prozessen. Biochemische Zeitschrift 22, 352-356.

Stent, G. \& BrenNer, S. (196I). A genetic locus for the regulation of RNA synthesis. Proceedings of the National Academy of Sciences of the United States of America 47, 2005-20I4.

SUEOKA, N. (1960). Mitotic replication of deoxyribonucleic acid in Chlamydomonas reinhardi. Proceedings of the National Academy of Sciences of the United States of America 46, 83-91.

TSCHIERSCH, B. (I966). Non-competitive inhibition of enzymatic reactions by canavanine. Tetrahedron Letters 28, 3237-324I.

WALKER, J. B. (1955). Canavanine and homoarginine as antimetabolites of arginine and lysine in yeast and algae. Journal of Biological Chemistry 212, 207-21 5. 